\title{
Pondok Pesantren: Its contributions on the Indonesian Muslim Middle Class
}

\author{
Muhammad Syaifudin ${ }^{a}$, Akhmad Mujahidin' ${ }^{b}$ Riki Rahmanc , Habibis Saleh ${ }^{\text {, }}$, and Harliana Halim ${ }^{\mathrm{e}}$ \\ $\mathbf{A}, \mathbf{b}, \mathbf{d}$ \\ Universitas Islam Negeri Sultan Syarif Kasim Riau, 28293, Pekanbaru, Riau, \\ Indonesia \\ $\mathrm{c}, \mathrm{e}$ \\ Centre for General Studies and Co-Curricular, Universiti Tun Hussein Onn \\ Malaysia, 86400, Parit Raja, Batu Pahat, Johor, Malaysia
}

Article History: Received: 11 January 2021; Accepted: 27 February 2021; Published online: 5 April 2021

\begin{abstract}
Pesantren has played an important role in the development of the Muslim middle class community in Indonesia. There is no denying that its contributions in developing the Muslim middle class in terms of education, economy and social is enormous. Thus, this article will identify the contribution of pesantren towards development of the Muslim middle class community in Indonesia. This article is a qualitative research. Therefore, the data used are secondary data taken from books, journals, reports, newspapers and internet sources are used as a reference in this study. The results of the study found that the contribution of pesantren towards educational, economic and social development of the Muslim middle class is enormous. Those contributions make Muslim middle class in Indonesia grow and develop.
\end{abstract}

Keywords: Pesantren, Muslim middle class, role, contribution

\section{Introduction}

The 'Pondok Pesantren' or Islamic Boarding School is an unlimited term for use in traditional Islamic educational institutions in Indonesia but is also applied throughout the Malay world. Nevertheless, besides 'Pondok Pesantren', there are many other names assigned to traditional Islamic education (Zakaria, 2010). In Aceh, the term used is 'Dayah'; in Minangkabau is 'Surau' and in some parts of the Malay world the term 'Sekolah Arab' is commonly employed (Dhofier, 1984). In addition, in Southern Thailand and in Malaysia, the term 'Pondok' is most well-known (Madmarn, 2001; Rahman, 1992).

Historical record told that pesantren is an educational institution that existed long before the formation of the Republic of Indonesia. Pesantren is often used as a center or base camp to struggle against the colonial at the time. Nahdlatul Ulama once wrote that the students then formed a line of Hizbullah, which later became one of the seeds of the military establishment. If in the era of colonialism, pesantren has a role as a stronghold of the people against the colonialists, then in relation to the democratic Indonesia, pesantren have a role as one supporting component of the defense system within the country's defense system (Francoise, 2017).

Nowadays, pondok pesantren become society based curriculum. Thus, pondok pesantren become the social institutions that continue to respond messy issues surrounding its society. Pondok pesantren acquire its additional function, namely as a center for society empowerment. Therefore, so many pondok pesantren that is made as a test for people's empowerment. For example, Pesantren Darul Falah Bogor, Pesantren Pabelan Magelang, Pesantren Kajen Pati, Pesantren Langitan Tuban, Pesantren An-Nuqayah Madura and others that serve as centers of society empowerment. The bustle of society empowerment then be outstanding in pondok pesantren. Further, in 2000s, pondok pesantren acquire its additional function again as central of social economy development. Then came pondok pesantren with his trademark develop cooperatives, such as pondok pesantren Sidogiri. This condition marked that truly, pondok pesantren is not devoid of innovation and it also indicates that pondok pesantren has very high response to changing times. So, in fact pesantren is a social and educational institution, and also economic society empowerment (Nuha, 2016).

Based on this, pesantren certainly has a role in developing the country, especially among the Muslim middle class in Indonesia through various ways. Therefore, the objective of this article is to identify the contributions of pesantren from the educational, economic and social aspects towards development of Muslim middle class.

\section{Methodology}

In order to reach this objective, this article has used secondary data by using library research. The required data is collected through library resources such as books, journals, authoritative internet materials and any previous works related to the objectives of this article directly or indirectly. These secondary data have been collected for almost four months. Then, these data have been analysed following predetermined themes by using 
descriptive-analytic method. The using library research based on research approach in order to investigate and explore the contributions of pesantren to build and develop Muslim middle class in Indonesia.

\section{Literature Review on Pesantren in Indonesia}

There are several articles that discussed about pesantren in Indonesia. Isbah (2020) studies on the development and modernization of pesantren in Indonesia in terms of curriculum since before independence until present. Nuha (2016) studies on the role of pondok pesantren in encountering Asean Economic Community (AEC). Francoise (2017) studies on the existence of pesantren as the unique source and very potential for creating Indonesian peace leaders in the future. This is because Muslims majority in Indonesia send their children to the pesantren to have a good education and good manner as well. Zamzami (2017) examines the role of pesantren as an institution of education and learning of social life. While Hadiono (2015) studied the role of pesantren as an educational institution to build the morals of adolescents living around pesantren. According to him, this matter is very important where the moral is the guidelines of daily life that must be implemented. Rasyid (2012) Rashid discusses the integration of pesantren curriculum, which is between the traditional curriculum using the 'Kitab Kuning' and the national curriculum. The integration of this curriculum should be implemented to meet the challenges of modernization in the world of education. Zakaria (2010), on the other hand, discusses the challenges and survival of pesantren in the future due to the current globalization and modernization of the education curriculum in Indonesia.

Unfortunately, their writings are mainly about the role of pesantren as an educational institution, pesantren curriculum and pesantren curriculum changes that must be implemented following the development of the times. Meanwhile, the issue of the contributions of pesantren against the rise of middle class Muslim communities was forgotten. In fact, the issue of the role of pesantren is very important to be discussed to determine the contributions of pesantren specifically in the development of the Muslim middle class. Consequently, this article discusses the contributions of pesantren in the rise of the Muslim middle class communities in Indonesia.

\section{Pesantren in Indonesia}

Pesantrens as non-formal education are educational institutions and traditional Islamic dakwa. Traditional pesantren schools are also the oldest educational institutions in Indonesia because they are in line with the spread of Islam in Indonesia. This is evidenced by the establishment of pesantren since the 15th century, such as Gelogah Arum which was founded by Raden Fatah in 1476 to the 19th century with several pesantrens led by Islamic guardians (wali), such as the Pesantren Sunan Malik Ibrahim in Gresik, the Pesantren Sunan Bonang in Tuban, Pesantren Sunan Ampel in Surabaya and the leading Pesantren Tegal Sari in Java (Azhari, 2014).

Before 1960, pesantren were known as pondok. The term pondok comes from the meaning of the santri's dormitory or a place to live made of bamboo. Pondok also comes from the Arabic word funduq, which means hotel or hostel. Meanwhile, the word pesantren comes from the word santri, which with the prefix 'pe' in front and the suffix 'an' means the residence of the santri. Professor Johns argues that the term santri comes from the Tamil language, which means teacher of the Koran. Meanwhile C.C. Berg argues that the term comes from the term shastri which in Indian means a person who knows the sacred books of Hinduism, or an expert on Hindu scriptures. The word shastri comes from the word shastra which means holy books, religious books or books about science. From the origin of the word santri, many scholars argue that pesantren institutions are basically religious educational institutions of the Indonesian nation during the Hindu-Buddhist religion called mandala which was later converted to Islam by the kyai (Islamic cleric) (Dhofier, 1984).

Researchers have different opinions about the oldest pesantren in Java. Some say that the oldest pesantren in Java is the Pesantren Tegalsari which was founded in 1742. However, according to Van Bruinessen, institutions that are similar to pesantren are only found in Priangan, Pekalongan, Rembang, Kedu, Madiun, and Surabaya (Bruinessen, 1995). Another report says that the oldest pesantren is pesantren Giri in the north of Surabaya, East Java which was founded by Sunan Giri in the 17th century (Syafe'i 2017). Mastuhu gave another conclusion, that pesantren in the Nusantara had existed since the 13-17th century, and in Java from the 15-16th century along with the entry of Islam in Indonesia. Mastuhu's report was corroborated by Dhofier that in Senthini literature it was explained that in the 16th century there were many prominent pesantren in Indonesia that had become centre of Islamic education (Dhofier, 1984). However, Mastuhu and Dhofier's report was rejected by Van Bruinessen, wherein the Senthini literature were written in the 19th century, therefore it cannot be considered as a reliable source to explain the events of the 17th century (Bruinessen, 1995). What can be concluded from the various views above is that the existence of pesantren as an educational institution and the spread of Islamic dakwa has been around for a long time, even long before Indonesia's independence.

Based on the curriculum or education system used, pesantrens have three types, namely: 1) Traditional pesantren (salaf). This pesantren still maintains its original form by teaching books written by 15th century scholars using Arabic language. The teaching pattern is by applying the halaqah system, in which a teacher or 
kyai conveys his knowledge and the santris (pesantren's students) surround him. This pattern is usually carried out in mosques. The essence of this halaqah teaching system is memorization, which in terms of methodology tends to create santris who receive and possess knowledge. This means that knowledge does not develop towards the completeness of that knowledge, but is only limited to what the kyai gives. The curriculum is entirely determined by the kyai. 2) Modern pesantren (khalaf). This pesantren is a development of the traditional type of pesantren because its learning orientation tends to adopt the whole classical learning system and leave the traditional learning system. The application of this modern learning system is especially evident in the use of learning classes in the form of madrasah or school. The curriculum used is the national curriculum. The position of the kyai is as the coordinator of the learning process and as a teacher in the classroom. The difference with schools and madrasahs is that the portion of Islamic religious education and Arabic is more prominent as the local curriculum. 3) Comprehensive pesantren. This type of pesantren is a combination between traditional and modern education system. Education is applied by teaching the kitab kuning which is usually taught at night after Maghrib prayer and after Fajr prayer. The classical system learning process is carried out in the morning until noon like in madrasahs or schools in general. The three types of pesantren illustrate that pesantren is an Islamic educational institutions that run and develop in accordance with the demands of the times (Usman, 2013). There are three roles and functions of the pesantren according to the independent character of its emancipatory vision. First, as an Islamic education and teaching institution. Second, as an Islamic struggle and missionary institution. Third, as an empowerment and community service institution (Zamzami, 2017).

\section{Muslim Middle Class in Indonesia}

Sociologists generally divide the class of capitalist society into three, namely: 1) The upper class that has the productive resources and hold economic role as investor. 2) The middle class that has educational qualifications or technical training and economic role as white-collar workers or better known as the professionals (management and administration). 3) The lower class that has physical energy and become laborers or manual workers in the production of goods and services (Mariappan, 2000).

In modern era, the middle class is the group with most people in the developed and developing countries. However, Suryadinata says that the concept of middle class in the Asian context is unclear. Some refer to Muslim traders, administration officials, and professionals and army personnel. Others restrict it to professionals and entrepreneurs. Referring to the Western definition, the middle class in Indonesia is still small. In 1990, those referred to as the middle class are "professional and technical" and "managers and administrators" groups who comprised only 3.9 percent of Indonesia's population at that time (Suryadinata, 1997).

According to Karl Marx, farmers, small entrepreneurs and small traders are the remnants of the pre-capitalism economy. This group was known as the middle class which was basically a group from the period of transition. They were also considered as small bourgeoisie that have conservative tendencies mindset. They were ranked between the working class and the capitalist class and landlords. With the existence of the transitional position, it is said to blur the boundaries between the workers and the bourgeois (Rahardjo, 1999).

Unlike Marx, the founder of modern sociology, Max Weber divided capitalist society economically into five classes, namely (1) the bourgeoisie class, (2) the working class, (3) the educated class, (4) the managers or administrators class, (5) small bourgeoisie, which refers to the traditional small bourgeois made up of businessmen, traders and farmers. This last group was closest to Marx's opinion (Rahardjo, 1999). The middle class itself can be divided into three parts, the upper-middle class, mid-middle class and lower-middle class (Yaakub, 1987).

Upper-middle class comprised of professional management and administration of the highest level. Midmiddle class was staffed by other professionals such as doctors, lawyers, engineers, lecturers, accountants, and others. Meanwhile the lower-middle class comprised of low level service workers (Mariappan, 2000). Regardless, what is meant by middle class communities are those whose position are between the working class and the bourgeoisie or between the upper class and the lower class. In the context of this discussion, it is understood that middle class Muslim communities are group of Muslims who are placed between the working class and the bourgeoisie or between upper and lower class communities whose livelihoods are lucrative and well educated.

The emergence of the middle class Muslim in Indonesia during the Dutch colonial era can be seen from the birth of the Syarikat Islam (SI) in the 1910s which had hundreds of thousands of members and Jong Islamieten Bond (JIB), the 1920s Islamic youth organization with its leaders KH. Agus Salim and H.O.S. Tjokroaminoto. Then the establishment of the Masyumi Party in the Old Order period followed. The emergence of middle class Muslims in both eras was more likely to be preceded by political movements and Islamic organisations. This is in contrast to the rise of the middle class Muslim communities in the New Order era which resulted from education and thought movement.

There are three classes of middle class Muslim communities in Indonesia, namely: First, modern elderly, especially Masyumi party supporters, who strived to champion formal political pursuit (Rahardjo, 1993). However, since Masyumi was banned and not authorized to carry out political activities, this group changed its 
struggle by establishing Parmusi (Indonesian Muslim Party) (Effendy, 1998). Secondly, young people who are not directly involved with Masyumi, those who did not form a new party but participated in the New Order political activity through recognised existing parties. They continued to be involved in the bureaucracy and support the modernist movement (Rahardjo, 1993). Thirdly, the younger generation. Although this group supported the elderly in the politics and the young people in the bureaucratic matters, their tendency was to build the basic structure necessary to support a more democratic political system. In other words, this group was more interested in community development activities and engaged in the fields of thought and education, rather than political or bureaucratic matters (Rahardjo,1993).

\section{Pesantren Contributions to Muslim Middle Class}

In Indonesia, pesantren has big roles in growing and developing Muslim middle class. This part would explain pesantren contributions towards social, educational and economic development.

\subsection{Social}

There are several contributions of pesantren identified from the social aspect, among them are against the colonialist and communist, as an Islamic centre, as agent of social change and the role of pesantren's alumni.

\subsubsection{Against the Colonialist and Communist}

Before independence, pesantren became a basis for the struggle of the indigenous-nationalists against the colonialists such as peasant uprising in Cilegon-Banten (1988), jihad of Acehnese (1873) and resistance by Kyai Ahmad Ripangi Kalisalak which is a leader of pesantren in village of Kalisalak, Central Java (1786) (Syafe'i, 2017). At the beginning of the Japanese occupation, the pesantrens were confronted with the new imperialists because of the refusal of Kyai Hasyim Asy'ari which was then followed by other kyai to the Saikere ceremony (honoring the emperor Tenno Haika as a descendant of God of Amaterasu) by bending down 90 degrees facing Tokyo every day at $07.00 \mathrm{am}$. Because of this refusal they were arrested and imprisoned by the Japanese. Thousands of santri and kyai demonstrated to the prison which later awakened the pesantren world to carry out an underground movement against Japan (Arifin, 1993); Bruinessen, 1994). The demonstration made Japan aware of how much influence the kyai had. Japan views that this action is not only unfavorable, but is a fatal mistake, especially in the effort to recruit military forces to face the enemy. Finally, Kyai Hasyim was released and from then on, Japan did not interfere any kyai and their pesantren (Mahdi, 2013).

After independence, santris also played a role in opposing the communist movement. Communists in Indonesia were pioneered by the PKI (Indonesian Communist Party). Many kyai and santri were killed during the PKI movement from the 1920s to the 1960s. Due to the movement carried out by the PKI in overthrowing the government, especially in the last PKI movement in 1965 and their actions in killing the ulama and santri, then this religious group, especially the kyai and santri are coming from NU (Nahdlatul Ulama) group rose up against the PKI (Fealy and McGregor, 2010; Mubarok, 2017). Together with the army and other groups of society, kyai and santri succeeded in eliminating the PKI and its supporters in the 1970s. With the end of colonialism and communist movement, the people in general and the Muslim middle class in particular could carry out their economic, social and economic activities more safely, smoothly and freely.

\subsubsection{As an Islamic Centre for the Surrounding Community}

Pesantren also being the role model and centre of Islamic activities to the surrounding community such as pengajian, yasinan, aqiqah and other activities that held in pesantren by inviting surrounding community. It must always be remembered that pesantren must be a "home" in developing mental and spiritual in accordance with the demands of times. Pesantrens, which are based on Islam, must be able to maximize the aspect of da'wah because da'wah is an inseparable part of Islamic sciences. By making pesantren as a role model and centre of socio-religious activities, the surrounding community, both from the poor, rich and middle class, will look up and respect the pesantren institution. That way, the dakwah processes carried out by the pesantren will be easier and more effective because they will be more easily accepted by the surrounding community

\subsection{Agent of Social Change}

Pesantren also have a social responsibility as agents of change. Such as changing attitudes and morals for the better for adolescents around the pesantren area which is mostly inhabited by Muslim middle class. For example, the Darussyafa'ah Islamic Boarding School in Siliragung, Banyuwangi, East Java uses the lecture and questionand-answer method, conducts intensive Islamic studies every month and holds a routine recitation program once a week for adolescents around the pesantren. Another social responsibility is to provide opportunities for local youth to gain knowledge at the pesantren as has been done by Pesantren Darussaya'ah (Hadiono, 2015). 


\subsubsection{Role of Pesantren's Alumni}

All pesantren alumni are spread all over Indonesia and abroad to become well-known public figures such as KH Wahid Hasyim, M. Nastir, Buya Hamka, Mukti Ali, Quraish Shihab, Abdurrahman Wahid (Gusdur) and time being a phenomenal ustadz appeared, namely ustadz abdul somad. Among these public figures there are those who hold high state positions such as ministers and president. They come from the pesantren education background and Muslim middle class. Therefore, the role of pesantren's alumni is very important in building and advancing the country.

\subsection{Education}

The contributions of pesantren from education aspect can be seen from development of pesantren, the public figures from pesantren alumni and performing majlis taklim and tabligh akbar.

\subsubsection{Development of Pesantren}

In 1942 the number of pesantren in Java island reached 1,871. In 1978, this number continued to increase, with the number of pesantren on the islands of Java and Madura reaching 3,195, and the number of students as many as 677,384 (Dhofier, 1984). Then in 1982 the number of pesantren throughout Indonesia reached 4,980 with 735,417 students (Azra, 1997). This number increased tremendously in 1985, when the pesantren numbered around 6,239 with a total of 1,084,801 students. Two decades later, in 1997, the number of pesantren had increased by $224 \%$ or 9,388 and the increase in the number of santri reached $261 \%$ or $1,770,768$ people. In 2001 , the number of pesantren throughout Indonesia had reached 11,312 with 2,737,805 students. This number includes salafiyah, traditional to modern (Syafe'i, 2017). Now, based on data accessed at the Ministry of Religion at the time this article was written, in 2020, it shows that the number of pesantren has increased drastically, reaching 27,218 pesantren both salafiyah, traditional or modern. While the number of students reached 3,642,738 people (http://pendis.kemenag.go.id/file/dokumen/bukusaku1102.pdf). After running for hundreds of years, pesantrens are seen as a stable and excellent educational institution such as Pesantren Modern Gontor, Pesantren Lirboyo, Pesantren Musthafawiyah, Pesantren Darunnajah Jakarta and Pesantren Tebu Ireng.

Pesantren have also succeeded in developing higher education institutions. In 2001, Pesantren Kalibeber, Wonosobo, Central Java founded the UNSIQ (Universitas Sains Al-Qur'an) (Usman, 2013). Pondok Pesantren Gontor has also succeeded in pioneering Unida (Universitas Darussalam Gontor) since 1963 under the name Darussalam Education Institute. In 2014, this institution was officially established as a university. These educational institutions are very important to educate the children who generally come from the Muslim middle class community.

\subsubsection{Performing Majlis Taklim and Tabligh Akbar}

Performing majlis taklim and tabligh akbar held by some institution or organization. This program normally is inviting ustadz or kyai from pesantrens or who has educational background from pesantren. There are also ustadzs who are invited to deliver their tausiyah or da'wah through broadcasts on television such as Ustadz Abdul Somad, Ustadz Zulkifli Muhammad Ali and Habib Syech Bin Abdul Qadir Assegaf. This is one of form of education for the community by using da'wa approach. Da'wah that is delivered directly or indirectly, either through television broadcasts or delivered in mosques, is enlightening and educating the ummah. The role of the kyai or ustadz is to guide the ummah to the straight path. If the ummah has been guided, it will be easy for the community to form a strong, honest, trustworthy, non-corrupt, and fair national character. That way, all people will feel the enjoyment of a developed and prosperous country.

\subsection{Economy}

Pesantrens are generally self-sufficient in terms of funds, because they do not receive regular funding from the government. therefore, the pesantrens will open their own business for their survival, such as opening agricultural fields, livestock, cooperative companies and other small and medium enterprises. Although the contribution of pesantren from an economic aspect may not be too large for the Muslim middle class, at least they employ local people in the sector of business they build. For example, in 1974, the Pesantren Ma'had Hadis in Bone, South Sulawesi succeeded in pioneering the establishment of a pesantren cooperative, the result of a collaboration with the Bone Regency Cooperative Office. The santris were also given the trust to manage the clove garden belonging to the pesantren. This effort are the most important parts in supporting the regular financing of pesantren (Usman, 2013). In 2018, there were 134 pesantrens that already had their own business units. The government is trying to help another 250 pesantrens to start their own businesses (https://finance.detik.com/berita-ekonomi-bisnis/d-4338908/bi-ajak-250-pesantren-kembangkan-unit-usaha).

\section{Conclusion}

The Muslim middle class in Indonesia is the largest part of society. They can come from various backgrounds such as lecturers, teachers, engineers, lawyers, middle-class entrepreneurs, technocrats and so on. Today's Muslim middle class society in Indonesia has made significant progress. There are those who become high leaders of the 
country. The progress and development of this Muslim middle class society cannot be separated from the contributions of various parties and institutions. Pesantren, as one of the educational institutions, is one of the many parts that make a large contribution to the Muslim middle class. Through the social, education and economic sectors, pesantrens have played their role as contributors to the development of Muslim middle class of this country. The development of the Muslim middle class has made the position of Muslims drastically changed socially, educationally and economically and has a high bargaining position. The Muslim middle class could be an influential movement in the centre of power and creates a new balance in pluralist Indonesian Society.

\section{References}

1. Arifin I 1993 Kepemimpinan Kiyai Kasus pondok Tebuireng (Malang: Kalmasahada Press)

2. Azhari 2014 Islamic Stud. J. 2 51-65

3. Azra A 1997 Pesantren Kontinuitas dan Perubahan, in foreword of Nurcholis Majid, Bilik-Bilik Pesantren: Sebuah Potret Penjalanan (Jakarta: Paramadina)

4. Bruinessen M V 1995 Kitab Kuning Pesantren dan Tarekat (Bandung: Mizan)

5. Bruinessen M V 1994 NU Tradisi Relasi-Relasi Kuasa Pencarian Wacana Baru (Yogyakarta: LkiS)

6. Dhofier Z 1984 Tradisi Pesantren: Studi Pandangan Hidup Kyai dan Visinya Mengenai Masa Depan Indonesia (Jakarta: LP3ES)

7. Effendy B 1998 Islam dan Negara; Transformasi Pemikiran dan Praktik Politik Islam di Indonesia (Jakarta: Paramadina)

8. Fealy G and McGregor K 2010 Indonesia 89 37-60.

9. Francoise J 2017 Walisongo: J. Penelitian Sos. Keagamaan 25 41-62

10. Hadiono A F 2015 Darussalam 7 80-95

11. https://finance.detik.com/berita-ekonomi-bisnis/d-4338908/bi-ajak-250-pesantren-kembangkan-unitusaha

12. http://pendis.kemenag.go.id/file/dokumen/bukusaku1102.pdf

13. Isbah M F 2020 Qudus Int. J. of Islamic Stu. 8 65-106

14. Madmarn H 2001 Pondok dan Madrasah di Patani (Bangi: Universiti Kebangsaan Malaysia)

15. Mahdi A 2013 J.L ISLAMIC REV. 2 1-20

16. Mariappan K 2000 Ketidaksamaan Sosial (Kuala Lumpur: Utusan Publications)

17. Nuha U 2016 ADDIN $10365-378$

18. Rahardjo M D 1999 Masyarakat Madani: Agama, Kelas Menengah, dan Perubahan Sosial (Jakarta: LP3ES-LSAF)

19. Rahardjo M D 1993 Intelektual Intelegensia dan Perilaku Politik Bangsa: Risalah Cendekiawan Muslim (Bandung: Penerbit Mizan)

20. Rahman I A 1992 Pendidikan Islam Malaysia (Bangi: Universiti Kebangsaan Malaysia)

21. Rasyid R 2012 JICSA 01 1-16

22. Suryadinata L 1997 Asian Survey 37 269-280

23. Syafe'i I 2017 Al-Tadzkiyyah: J. Pend. Islam 8 85-103

24. Usman M I 2013 J. Al Hikmah 14 101-119

25. Yaakub N F 1987 Pengantar Sosiologi (Petaling Jaya: Penerbit Fajar Bakti Sdn Bhd)

26. Zakaria G A N 2010 J. of Islamic and Arabic Ed. 2 45-52

27. Zamzami M R 2017 Ta'limuna 6 21-32. 